\title{
The Determination of Plant Nutrients Taken from Soil of Black Cumin (Nigella sativa L.) as Traditional Spice
}

\author{
Ahmet Gümüş̧̧ü \\ Department of Medicinal and Aromatic Plants, Çumra Vocational College, Selçuk University, Çumra 42500, Konya, Turkey
}

Received: October 31, 2013 / Published: December 20, 2013.

\begin{abstract}
This study was carried out under Çumra-Konya conditions, in 2007, for the determination of consumption of the plant nutrients from soil by black cumin plants. The soil samples were taken before sowing and after harvest from the field that was sown black cumin and determined the rate of major and minor plant nutrients. For this reason, soil samples were taken from the depth of 30 $\mathrm{cm}$ as 2-3 $\mathrm{kg}$ and analyzed. The harvested black cumin yielded approximately $1,350 \mathrm{~kg} / \mathrm{ha}$ seed. The analyses made in soil samples were $\mathrm{pH}$, salinity, organic matter and lime, $\mathrm{P}, \mathrm{K}, \mathrm{Ca}, \mathrm{Mg}, \mathrm{Na}, \mathrm{Cu}, \mathrm{Fe}, \mathrm{Zn}$ and $\mathrm{Mn}$. According to the results, the parcel soil has not salt problem, and is little alkaline, more limy and little humic, good for phosphorus and very rich with respect potassium before sowing. At the same time, the parcel soil samples after harvest were little saline, little alkaline, more limy, poor humic, good for phosphorus and very rich with respect potassium.
\end{abstract}

Key words: Black cumin, soil analyses, plant nutrient, Konya.

\section{Introduction}

The black cumin, Nigella sativa L. has been shown to contain $30 \%$ of fixed oil and $0.4 \%-0.45 \%$ volatile oil. The volatile oil has been shown to contain $18.4 \%-24 \%$ thymoquinone and $46 \%$ monoterpenes such as p-cymene and $\alpha$-piene [1]. This plant which grows to a maximum height of about $60 \mathrm{~cm}$, has finely divided foliage and blue flowers from which are produced small caraway-type black seeds [2]. The plant has been found to be salt tolerant and may be considered as glycophyte [3].

Black cumin tastes slightly bitter and peppery with a crunchy texture. Seeds are angular of generally small size (1-5 mg), dark grey or black color [4]. N. sativa seeds are used for edible and medicinal purposes in many countries like Turkey.

Black cumin seeds have been used as a condiment in bread and other dishes, and they have also been used in the preparation of a traditional sweet dish, composed of

Corresponding author: Ahmet Gümüşçü, associate professor, research fields: medicinal and aromatic plants, cultivation and technology. E-mail: agumuscu19@yahoo.com. black cumin paste, which is sweetened with honey or syrup, and in flavoring of foods, especially bakery products and cheese. $N$. sativa seed oil is considered as one among newer sources of edible oils, thanks to its important role in human nutrition and health [5-7].

Seed of Nigella sativa L., an annual spice which is also known as black cumin or black caraway, is a member of the Ranunculaceae family and native to some parts of the Mediterranean region. These seeds are not related to cumin or caraway, both of which belong to the Umbelliferous family [8]. The seeds are used for edible and medicinal purposes in many countries including India, Egypt and Syria. Recently, many medicinal properties have been attributed to the black cumin seeds and/or its oil, including antineoplastic (antitumor), antibacterial, antifungal and antihelmenthic properties [9-11]. More recently, a great deal of attention has been given to the black cumin seeds and their oil, and their consumption has thus increased, especially in Middle East countries. But there are few studies of the oil characteristics and fatty acid composition of black cumin. 
Gad et al. [12] studied the physical and chemical characteristics and fatty acid composition of the oil extracted from the Egyptian Nigella sativa L.. According to their study, the saturated fatty acids constituted $11.8 \%$ of total fatty acids and consisted of myristic, palmitic and stearic acids, while the spectrophotometric determination of the unsaturated acids showed the presence of oleic $(48.76 \%)$, linoleic $(37.56 \%)$ and linolenic $(1.88 \%)$ acids.

The spicy seeds from this plant have proclaimed medicinal usage dating back to the ancient Egyptians, Greeks and Romans. In his Canon of Medicine, Avicenna stated that the black seed acts as an expectorant, it stimulates the body's energy and helps recovery from fatigue and dispiritedness. In Islamic medicine, however, the use of the seeds is recommended in daily use because it has prophesised cure for all known diseases [13, 14].

The aim of this study was to determine which and how many major and minor plant nutrients were taken from soil by black cumin under Konya (Central Anatolia) conditions. Accordingly, some recommendations will be done to the black cumin producers in Konya and other regions.

\section{Materials and Methods}

\subsection{Materials}

Black cumin samples were taken as material from different regions which produce black cumin via Konya Commerce Chamber. This study was planned on the experimental plots at the Selcuk University, Cumra Vocational College in Konya, in 2007.

\subsection{Methods}

The seed samples were sown regarding to randomized block design with three replications. Before sowing, the soil samples were taken from the planned parcels to sow black cumin.

The soil samples were taken according to the soil sampling rules. Therefore, first of all, upper layer by $4-5 \mathrm{~cm}$ of soil was removed and a soil layer by $30 \mathrm{~cm}$ depth was taken by a shovel. All the samples were mixed and filled to plastic bags. Then, these samples were transferred for analysing to the laboratory. This process was replicated after harvest.

\subsection{Data Analysis}

The data related to plant yield collected from all the parcels, were evaluated as mean value and represented in this paper. Other data related to soil sample analysis were collected and evaluated separately before sowing and after harvest. Then, the data collected from soil parcel before sowing were compared with the data from after harvest.

\section{Results and Discussion}

As it is understood in Tables 1 and 2, there is not salt problem on this parcel soil. It is little alcaline, but more limy and little humic. The phosphorus level among essential plant nutrients is good and potassium level is very high. Because it is more limy, it is expected that calcium is rich in the soil. Also, the soil is good in terms of magnesium, it has enough copper and manganese, which are minor plant nutrients, but it has deficiency in terms of iron and zinc elements.

As it is seen in Table 2, the soil of this parcel has no salt problem, it is little alkaline, more limy and little humic with regards to organic matter. The phosphorus level among essential plant nutrients is good and very rich with respect potassium. Because the soil is more limy, it is rich with regard calcium. It is seen that the soil with good level of magnesium, has enough copper and manganese, but the iron level is middle and it has not enough zinc.

Cheikh-Rouhou et al. [7] conducted some trials related to the chemical components of both Tunisian and Iranian black cumin seeds. According to the results, some characters and minerals ratio in the seeds are: dry matter $(91.35 \pm 0.26) \%-(95.92 \pm 0.70) \%$; oil $(28.48 \pm$ $0.05) \%-(40.35 \pm 0.16) \%$; crude protein $(26.7 \pm$ $0.35) \%-(22.6 \pm 0.24) \%$; ash $(4.86 \pm 0.06) \%-(4.41 \pm$ $0.01) \%$; K (783 \pm 6.61$)$ ppm-(708 \pm 7.98) ppm; $\mathrm{Mg}$ $(235 \pm 4.87)$ ppm-(260 \pm 48.70$)$ ppm; 
Table 1 The analysis results of soil samples of black cumin parcels before sowing (30 cm depth).

\begin{tabular}{lllll}
\hline Parcel 7 & & & & 2007.03 .16 \\
\hline Analysis & Unit & Method & Result & Comment \\
\hline $\mathrm{pH}(1: 2.5$, soil:water) & & $1: 2.5$ & 7.62 & Little alkaline \\
$\mathrm{EC}($ salt $)(1: 5$, soil:water) & $\mu \mathrm{S} / \mathrm{cm}$ & $1: 5$ & 168 & No salt \\
$\mathrm{CaCO}_{3}($ lime $)$ & $\%$ & Calsimeter & 19.1 & More limy \\
Organic matter & $\%$ & W. Black & 1.113 & Little humic \\
Phosphor $\left(\mathrm{P}_{2} \mathrm{O}_{5}\right)$ & $\mathrm{mg} / \mathrm{kg}$ & NaHCO ${ }_{3}$ ext. & 8.95 & Good \\
Potassium $(\mathrm{K})$ & $\mathrm{mg} / \mathrm{kg}$ & A.Ac. ext. & 744.96 & Very rich \\
Calcium $(\mathrm{Ca})$ & $\mathrm{mg} / \mathrm{kg}$ & A.Ac. ext. & 6,513 & Rich \\
Magnesium $(\mathrm{Mg})$ & $\mathrm{mg} / \mathrm{kg}$ & A.Ac. ext. & 1,070 & Good \\
Sodium $(\mathrm{Na})$ & $\mathrm{mg} / \mathrm{kg}$ & A.Ac. ext. & 58.31 & Low \\
Copper $(\mathrm{Cu})$ & $\mathrm{mg} / \mathrm{kg}$ & DTPA ext. & 1.165 & Enough \\
Iron $(\mathrm{Fe})$ & $\mathrm{mg} / \mathrm{kg}$ & DTPA ext. & 2.201 & Deficient \\
Zinc $(\mathrm{Zn})$ & $\mathrm{mg} / \mathrm{kg}$ & DTPA ext. & 0.191 & Deficient \\
Manganese $(\mathrm{Mn})$ & $\mathrm{mg} / \mathrm{kg}$ & DTPA ext. & 3.411 & Enough \\
\hline
\end{tabular}

Table 2 The analysis results of soil samples of black cumin parcels before sowing $(30 \mathrm{~cm}$ depth).

\begin{tabular}{lllll}
\hline Parcel 8 & & & & 2007.03 .16 \\
\hline Analiysis & Unit & Method & Result & Comment \\
\hline $\mathrm{pH}(1: 2.5$, soil:water) & & $1: 2.5$ & 7.83 & Little alkaline \\
$\mathrm{EC}(\mathrm{salt})(1: 5$, soil:water) & $\mu \mathrm{S} / \mathrm{cm}$ & $1: 5$ & 162 & No salt \\
$\mathrm{CaCO}_{3}($ lime $)$ & $\%$ & Calsimeter & 20.5 & More limy \\
Organic matter & $\%$ & W. Black & 1.26 & Little humic \\
Phosphor $\left(\mathrm{P}_{2} \mathrm{O}_{5}\right)$ & $\mathrm{mg} / \mathrm{kg}$ & NaHCO ext. & 14.03 & Rich \\
Potassium $(\mathrm{K})$ & $\mathrm{mg} / \mathrm{kg}$ & A.Ac. ext. & 738.72 & Very rich \\
Calcium $(\mathrm{Ca})$ & $\mathrm{mg} / \mathrm{kg}$ & A.Ac. ext. & 7,860 & Rich \\
Magnesium $(\mathrm{Mg})$ & $\mathrm{mg} / \mathrm{kg}$ & A.Ac. ext. & 1,197 & Good \\
Sodium $(\mathrm{Na})$ & $\mathrm{mg} / \mathrm{kg}$ & A.Ac. ext. & 97.12 & Low \\
Copper $(\mathrm{Cu})$ & $\mathrm{mg} / \mathrm{kg}$ & DTPA ext. & 1.196 & Enough \\
Iron $(\mathrm{Fe})$ & $\mathrm{mg} / \mathrm{kg}$ & DTPA ext. & 3.939 & Middle \\
Zinc $(\mathrm{Zn})$ & $\mathrm{mg} / \mathrm{kg}$ & DTPA ext. & 0.171 & Deficient \\
Manganese $(\mathrm{Mn})$ & $\mathrm{mg} / \mathrm{kg}$ & DTPA ext. & 3.614 & Enough \\
\hline
\end{tabular}

$\mathrm{Ca}(572 \pm 21.5) \mathrm{ppm}-(564 \pm 33.4) \mathrm{ppm} ; \mathrm{P}(48.9 \pm 0.04)$ ppm-(51.9 \pm 0.01$)$ ppm; Na (20.8 \pm 2.21$)$ ppm-(18.5 \pm 3.17) ppm; Fe (8.65 \pm 0.65$)$ ppm-(9.42 \pm 0.88$)$ ppm; $\mathrm{Cu}(1.65 \pm 0.03) \mathrm{ppm}-(1.48 \pm 0.21) \mathrm{ppm} ; \mathrm{Zn}(8.04 \pm$ $0.21) \mathrm{ppm}-(7.03 \pm 0.49) \mathrm{ppm}$ and $\mathrm{Mn}(4.43 \pm 0.11)$ ppm-(3.37 \pm 0.21$)$ ppm, respectively.

The information expressed till here was for seeing the plant nutrients in the soil before sowing black cumin. The soil samples were taken after harvest as well, to understand if the amounts of the plant nutrients changed or not, and if they changed, which direction was realized for this changing. According to soil sample rules, all the soil samples from parcels were mixed and packed as $2-3 \mathrm{~kg}$ in the nylon bags. These samples were transferred to the Sample Analyse Laboratory at the Konya Commodity Exchange Market. The data taken from the analyses were represented in the tables below (Tables 3 and 4).

As it is seen in Table 3, according to the analyse results, it is understood that the soil is little saline and little alkaline. It is more limy and poor humic as well. The phosphorus level among essential plant nutrients is good and very rich with respect potassium. The soil, which is rich with regards calcium, is good in terms of magnesium, enough for copper and manganese, but is also poor with respect iron and zinc. 
Table 3 The analysis results of soil samples of black cumin parcels after harvest.

\begin{tabular}{lllll}
\hline Parcel 7 & & & & 2007.09 .10 \\
\hline Analiysis & Unit & Method & Result & Comment \\
\hline $\mathrm{pH}(1: 2.5$, soil:water) & & $1: 2.5$ & 7.66 & Little alkaline \\
EC (salt) $(1: 5$, soil:water) & $\mu \mathrm{S} / \mathrm{cm}$ & $1: 5$ & 232 & Little saline \\
$\mathrm{CaCO}_{3}($ lime $)$ & $\%$ & Calsimeter & 20.24 & More limy \\
Organic matter & $\%$ & W. Black & 0.54 & Poor \\
Phosphor $\left(\mathrm{P}_{2} \mathrm{O}_{5}\right)$ & $\mathrm{mg} / \mathrm{kg}$ & NaHCO 3 ext. & 10.22 & Rich \\
Potassium $(\mathrm{K})$ & $\mathrm{mg} / \mathrm{kg}$ & A.Ac. ext. & 630.6 & Very rich \\
Calcium $(\mathrm{Ca})$ & $\mathrm{mg} / \mathrm{kg}$ & A.Ac. ext. & 7,429 & Rich \\
Magnesium $(\mathrm{Mg})$ & $\mathrm{mg} / \mathrm{kg}$ & A.Ac. ext. & 836.8 & Good \\
Sodium $(\mathrm{Na})$ & $\mathrm{mg} / \mathrm{kg}$ & A.Ac. ext. & 52.72 & Low \\
Copper $(\mathrm{Cu})$ & $\mathrm{mg} / \mathrm{kg}$ & DTPA ext. & 1.765 & Enough \\
Iron $(\mathrm{Fe})$ & $\mathrm{mg} / \mathrm{kg}$ & DTPA ext. & 1.278 & Deficient \\
Zinc $(\mathrm{Zn})$ & $\mathrm{mg} / \mathrm{kg}$ & DTPA ext. & 0.438 & Deficient \\
Manganese $(\mathrm{Mn})$ & $\mathrm{mg} / \mathrm{kg}$ & DTPA ext. & 4.625 & Enough \\
\hline
\end{tabular}

Table 4 The analysis results of soil samples of black cumin parcels after harvest.

\begin{tabular}{lllll}
\hline Parcel 8 & & & & 2007.09 .10 \\
\hline Analiysis & Unit & Method & Result & Comment \\
\hline $\mathrm{pH}(1: 2.5$, soil:water) & & $1: 2.5$ & 7.49 & Little alkaline \\
$\mathrm{EC}($ salt $)(1: 5$, soil:water) & $\mu \mathrm{S} / \mathrm{cm}$ & $1: 5$ & 191 & Little saline \\
$\mathrm{CaCO}_{3}($ lime $)$ & $(\%)$ & Calsimeter & 21.45 & More limy \\
Organic matter & $(\%)$ & W. Black & 0.97 & Poor \\
Phosphor $\left(\mathrm{P}_{2} \mathrm{O}_{5}\right)$ & $\mathrm{mg} / \mathrm{kg}$ & NaHCO ${ }_{3}$ ext. & 12.76 & Rich \\
Potassium $(\mathrm{K})$ & $\mathrm{mg} / \mathrm{kg}$ & A.Ac. ext. & 697.44 & Very rich \\
Calcium $(\mathrm{Ca})$ & $\mathrm{mg} / \mathrm{kg}$ & A.Ac. ext. & 7,578 & Rich \\
Magnesium $(\mathrm{Mg})$ & $\mathrm{mg} / \mathrm{kg}$ & A.Ac. ext. & 967.2 & Good \\
Sodium $(\mathrm{Na})$ & $\mathrm{mg} / \mathrm{kg}$ & A.Ac. ext. & 82.78 & Low \\
Copper $(\mathrm{Cu})$ & $\mathrm{mg} / \mathrm{kg}$ & DTPA ext. & 1.507 & Enough \\
Iron $(\mathrm{Fe})$ & $\mathrm{mg} / \mathrm{kg}$ & DTPA ext. & 1.055 & Deficient \\
Zinc $(\mathrm{Zn})$ & $\mathrm{mg} / \mathrm{kg}$ & DTPA ext. & 0.335 & Deficient \\
Manganese $(\mathrm{Mn})$ & $\mathrm{mg} / \mathrm{kg}$ & DTPA ext. & 4.037 & Enough \\
\hline
\end{tabular}

Comparing the soil analysis before sowing with that after harvest, it is seemed that black cumin used up more iron and manganaese, which are minor plant nutrients, and not more phosphorus and potassium, which are essential plant nutrients.

As it is understood from Table 4, according to the results of another after harvest parcel, the soil is little alkaline, little saline, more limy and enough for organic matter. The phosphorus level among essential plant nutrients is very good and very rich with respect potassium. The soil is determined rich in terms of calcium and magnesium, enough for copper and manganese, but poor for iron and middle for zinc.
The analysis results of soil sample before sowing and after harvest were represented as a table below. Some comments were done regarding droughtness in Turkey, in 2007. The best black cumin line yielded $1,350 \mathrm{~kg} / \mathrm{ha}$ and this yield was realized with one time irrigation. The rainfall is almost not seen during, before and after blooming including sowing time. This situation came into being huge yield problem by cultivated plants including black cumin in the whole country. But the enough plant samples having parcels were selected and yields were measured on these parcels. Because the soil samples were taken from each parcel, and the experimental error related to soil 
sample analysis was reduced to minimum.

As a conclusion, Tables 5 and 6 would give some information about some plant nutrients taken from soil by black cumin.

As seen in Table 5, the phosphorus among basic plant nutrients decreased to $7.68 \mathrm{mg} / \mathrm{kg}$ after harvest, while it was found $8.95 \mathrm{mg} / \mathrm{kg}$ in the soil before sowing. Also potassium decreased to $732.24 \mathrm{mg} / \mathrm{kg}$ from 744.96 $\mathrm{mg} / \mathrm{kg}$, and the iron among minor plant nutrients decreased to $1.405 \mathrm{mg} / \mathrm{kg}$ from $2.201 \mathrm{mg} / \mathrm{kg}$, too.

As it is understood from Table 6, some elements such as phosphorus, potassium and calcium taken by black cumin came to the fore as regards other plant nutrients comparison to other parcels. Among the plant nutrients, phosphorus, potassium and calcium decreased from $14.03 \mathrm{mg} / \mathrm{kg}$ to $13.61 \mathrm{mg} / \mathrm{kg}, 738.72$ $\mathrm{mg} / \mathrm{kg}$ to $561.84 \mathrm{mg} / \mathrm{kg}$ and $7,860 \mathrm{mg} / \mathrm{kg}$ to 7,724 $\mathrm{mg} / \mathrm{kg}$, respectively. The minor plant nutrients, iron and manganese decreased from $3,939 \mathrm{mg} / \mathrm{kg}$ to 1.650 $\mathrm{mg} / \mathrm{kg}$ and $3,614 \mathrm{mg} / \mathrm{kg}$ to $2.424 \mathrm{mg} / \mathrm{kg}$, respectively.

As a conclusion, in comparison of soil analyses before sowing and after harvest, it is understood that the black cumin took more iron and manganese from soil, and phosphorus and potassium were taken more

Table 5 The situation of plant nutrients in the black cumin sown soil before sowing and after harvest.

\begin{tabular}{llllll}
\hline \multirow{2}{*}{ Analysis } & \multicolumn{4}{c}{2007.03 .16} & 2007.09 .10 \\
\cline { 2 - 6 } & \multicolumn{4}{c}{ Before sowing } & After harvest \\
\cline { 2 - 6 } & Unit & Result & Comment & Result & Comment \\
\hline $\mathrm{pH}(1: 2.5$, soil:water) & & 7.62 & Little alkaline & 7.5 & Little alkaline \\
EC (salt) (1:5 soil:water) & $\% \mathrm{~S} / \mathrm{cm}$ & 168 & No salt & 210 & Little saline \\
CaCO $_{3}$ (lime) & $\%$ & 19.1 & More limy & 21 & More limy \\
Organic matter & $\%$ & 1.113 & Low humic & 1.38 & Low humic \\
Phosphorus $\left(\mathrm{P}_{2} \mathrm{O}_{5}\right)$ & $\mathrm{mg} / \mathrm{kg}$ & 8.95 & Good & 7.68 & Good \\
Potassium $(\mathrm{K})$ & $\mathrm{mg} / \mathrm{kg}$ & 744.96 & Very rich & 732.24 & Very rich \\
Calcium $(\mathrm{Ca})$ & $\mathrm{mg} / \mathrm{kg}$ & 6,513 & Rich & 7,752 & Rich \\
Magnesium $(\mathrm{Mg})$ & $\mathrm{mg} / \mathrm{kg}$ & 1,070 & Good & 1,155 & Good \\
Sodium $(\mathrm{Na})$ & $\mathrm{mg} / \mathrm{kg}$ & 58.31 & Low & 175.2 & Low \\
Copper $(\mathrm{Cu})$ & $\mathrm{mg} / \mathrm{kg}$ & 1.165 & Enough & 1.838 & Enough \\
Iron $(\mathrm{Fe})$ & $\mathrm{mg} / \mathrm{kg}$ & 2.201 & Deficient & 1.405 & Deficient \\
Zinc $(\mathrm{Zn})$ & $\mathrm{mg} / \mathrm{kg}$ & 0.191 & Deficient & 0.386 & Deficient \\
Manganese $(\mathrm{Mn})$ & $\mathrm{mg} / \mathrm{kg}$ & 3.411 & Enough & 6.936 & Enough \\
\hline
\end{tabular}

Table 6 The situation of plant nutrients in the black cumin sown soil before sowing and after harvest.

\begin{tabular}{|c|c|c|c|c|c|}
\hline \multirow{3}{*}{ Analysis } & \multicolumn{3}{|c|}{2007.03 .16} & \multicolumn{2}{|c|}{2007.09 .10} \\
\hline & \multicolumn{3}{|c|}{ Before sowing } & \multicolumn{2}{|c|}{ After harvest } \\
\hline & Unit & Result & Analysis & Result & Analysis \\
\hline pH (1:2.5, soil:water) & & 7.83 & Little alkaline & 7.55 & Little alkaline \\
\hline EC (salt) $(1: 5$, soil:water $)$ & $\mu \mathrm{S} / \mathrm{cm}$ & 162 & No salt & 455 & Saline \\
\hline $\mathrm{CaCO}_{3}$ (lime) & $\%$ & 20.5 & More limy & 52.72 & More limy \\
\hline Organic matter & $\%$ & 1.26 & Low humic & 1.31 & Low humic \\
\hline Phosphorus $\left(\mathrm{P}_{2} \mathrm{O}_{5}\right)$ & $\mathrm{mg} / \mathrm{kg}$ & 14.03 & Rich & 13.61 & Rich \\
\hline Potassium (K) & $\mathrm{mg} / \mathrm{kg}$ & 738.72 & Very rich & 561.84 & Very rich \\
\hline Calcium $(\mathrm{Ca})$ & $\mathrm{mg} / \mathrm{kg}$ & 7,860 & Rich & 7,724 & Rich \\
\hline Magnesium (Mg) & $\mathrm{mg} / \mathrm{kg}$ & 1,197 & Good & 1,411 & Good \\
\hline Sodium $(\mathrm{Na})$ & $\mathrm{mg} / \mathrm{kg}$ & 97.12 & Low & 412.4 & Little \\
\hline Copper $(\mathrm{Cu})$ & $\mathrm{mg} / \mathrm{kg}$ & 1.196 & Enough & 1.682 & Enough \\
\hline Iron $(\mathrm{Fe})$ & $\mathrm{mg} / \mathrm{kg}$ & 3.939 & Middle & 1.650 & Deficient \\
\hline Zinc $(\mathrm{Zn})$ & $\mathrm{mg} / \mathrm{kg}$ & 0.171 & Deficient & 0.602 & Middle \\
\hline Manganese (Mn) & $\mathrm{mg} / \mathrm{kg}$ & 3.614 & Enough & 2.424 & Enough \\
\hline
\end{tabular}


by black cumin among essential plant nutrients.

But this experiment does not represent all central Anatolia conditions. Therefore, the same experiments related this topic should replicate under other similar ecological conditions. Because the soil properties may change even in the same field and therefore this experiment should carry out under dry and irrigated conditions.

\section{References}

[1] K.E. El-Tahir, M.M. Ashour, M.M. Al-Harbi, The respiratory effects of the volatile oil of the black seed (Nigella sativa) in guinea-pigs: Elucidation of the mechanism(s) of action, Gen. Pharmacol. 24 (1993) 1115-1122.

[2] M.A. Khan, Chemical composition and medicinal properties of Nigella sativa L., Inflammopharmacology 7 (1) (1999) 15-35.

[3] A.S. Hajar, M.A. Zidan, H.S. A1-Zahrani, Effect of salinity stress on the germination, growth and some physiological activities of black cumin (Nigella sativa L.), Arab Gulf Journal of Scientific Research 14 (2) (1996) 445-454.

[4] M.A. Ali, M.A. Sayeed, M.S. Alam, S. Yeasmin, A.M. Khan, I.I. Muhamad, Characteristics of oils and nutrient contents of Nigella sativa Linn. and Trigonella foenum-graecum seeds, Bull. Chem. Soc. Ethiop 26 (1) (2012) 55-64.

[5] E.A. Aboutabl, A.A. El-Azzouny, F.J. Hammerschmidt, Aroma volatiles of Nigella sativa L. seeds, in: Progress in
Essential Oil Research, Walter de Gruyter and Co., New York, 1986, pp. 49-55.

[6] I. Merfort, V. Wray, H.H. Barakat, S.A.M. Hussein, M.A.M. Nawwar, G. Willuhn, Flavonol triglycosides from seeds of Nigella sativa, Phytochemistry 46 (2) (1997) 359-363.

[7] S. Cheikh-Rouhou, B. Souhail, H. Basma, B. Christophe, D. Claude, A. Hamadi, Nigella sativa L.: Chemical composition and physicochemical characteristics of lipid fraction, Food Chem. 101 (2007) 673-681.

[8] V.K. Babayan, D. Koottungal, G.A. Halaby, Proximate analysis, fatty acid and amino acid composition of Nigella sativa L. seeds, J. Food Sci. 43 (1978) 1314-1319.

[9] N.J. Salomi, S.C. Nair, K.K. Jayawardhanane, C.D. Varghese, K.R. Panikkar, Antitumour principles from Nigella sativa seeds, Cancer Lett. 63 (1992) 41-46.

[10] C.M. Hasan, M. Ahsan, S.N. Islam, In vitro antibacterial screening of the oils of Nigella sativa seeds, Bangladesh Journal of Botany 18 (2) (1989) 171-174.

[11] A.S.M. Hussein, Antibacterial and antifungal activities of some Libyan aromatic plants, Planta Medica 56 (1990) 644-645.

[12] A.M. Gad, M. El-Dakhakhny, M.M. Hassan, Studies on the chemical composition of Egyptian Nigella sativa L. oil, Planta Medica 11 (1963) 134-138.

[13] M.I. Al-Bukhari, S. A1-Bukhari, Authentic Narrations of Prophet Muhammad, M.M. Khan (Trans.), Madinah Islamic University, Saudi Arabia, 1982, Vol. 7, p. 400.

[14] I.I.Q. A1-Jawziyya, I.M. Al-Akili, Natural Healing with the Medicine of The Prophet, Pearl Publishing House, Philadelphia, USA, 1993, pp. 229-232. 